\title{
Tudo uma questão de Estética e Linguagem
}

DOI: 10.1590/1809-58442017214

\section{Rodrigo Gabrioti}

(Universidade Metodista de São Paulo, Escola de Comunicação, Educação e Humanidades, Programa de Pós-Graduação em Comunicação Social. São Bernardo do Campo - SP, Brasil)

BUCCI, Eugênio. A forma bruta dos protestos: das manifestações de junho de 2013 à queda de Dilma Rousseff em 2016. São Paulo: Companhia das Letras, 2016.

O mais recente livro de Eugênio Bucci recorre a um Brasil atual sob o olhar de apuração do repórter e o questionamento do pesquisador como ensaio de compreensão de um fervilhar sociopolítico para o qual o país foi alçado. Tal condição surge com o levante popular de 2013, quando brasileiros ocuparam as ruas para tentar despertar o gigante adormecido. A questão política é a matéria-prima para o trabalho do autor, que coloca a Comunicação como um processo empírico central, trazendo consigo algo de mais

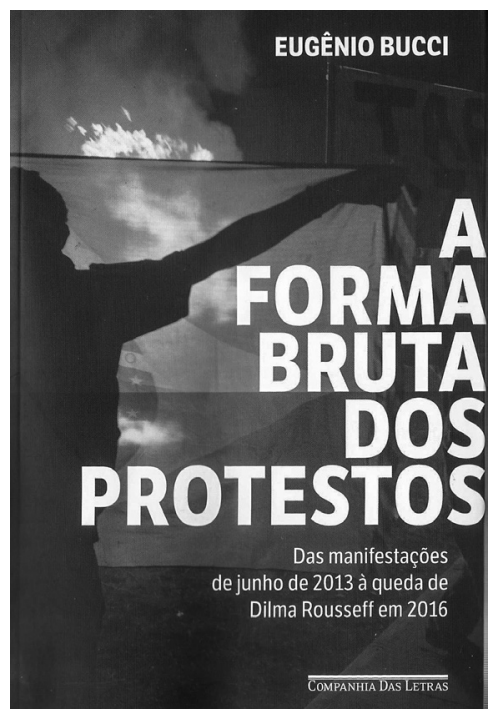
elementar da comunicabilidade: a mensagem. Mensagem que Eugênio Bucci considera como não compreendida em Brasília, o centro do poder, tanto por situação quanto oposição. Se no polo do receptor a mensagem falhou, pelo lado dos emissores, houve nas ruas uma estética, não artística, mas sim de experiência, visibilidade e interpretação. Em uma linguagem que se recicla tão rapidamente como as mídias da era digital, a estética da negação aos 20 centavos no aumento das passagens de ônibus serviu de estopim para as manifestações de rua que se convergiram ao movimento "Não vai ter Copa”.

A partir disso, o autor considera as representações, sendo a mais contundente a dos black blocs que, para Bucci, ganharam junto à mídia tradicional uma imagem de barbárie, haja vista suas ações sempre violentas. Eugênio Bucci considera que esse tipo de ação apesar da violência empregada - não deixava de ser uma contralinguagem contradiscursiva de protocolos discursivos no tocante à manutenção da ordem.

Na chamada Instância da Imagem ao Vivo, mesmo que um indivíduo ou grupo faça da contralinguagem seu discurso, sabe-se que há outras formas de se comunicar. Assim, em tempos de conexões, o exercício pleno de sua linguagem e estética não necessariamente se 
presume pela mídia tradicional, o que faz o autor abordar a transformação experimentada pela comunicação.

As novas possibilidades tecnológicas são mais ameaçadoras que os descontentamentos políticos em si, porque o alcance delas é intangível. Praticamente se irrompeu a mediação clássica jornalística do fato construído pela imprensa como relato. Há de se dizer que o livro não faz uma defesa ou uma crítica entre o certo e o errado. O que se coloca no texto é a consideração de linguagens cujas sintaxes se alteram e atendem a demandas. $\mathrm{O}$ autor quer dizer que, assim como o Jornalismo tem a sua tradição e gramática, as novas formas de expressão também as têm, ainda que os parâmetros sejam diferentes, questionáveis e passíveis de compreensão/interpretação nesta Era Digital que impôs à vida social um deslocamento tectônico.

À luz de novas práticas, o Bucci revisita conceitos teóricos. É assim quando introduz o Mundo da Vida, de Jürgen Habermas, como o lugar onde a vida cotidiana acontece. Assim, analisa as "Jornadas de Junho" como Mundo da Vida na esfera pública brasileira que se tornara mais complexo, mais aparelhado e mais vigoroso. Se todo o Mundo da Vida, como diz Habermas, é um espaço social gerado pela Comunicação, nada mais assertivo do que essa definição transcender o século XXI.

E essa transcendência trouxe ao Mundo da Vida um novo componente que proporcionou, ou pelo menos tentou - se é que não obrigou - repensar o Jornalismo, sobretudo, com uma prática alternativa: a Mídia Ninja. Seus ativistas eram ao mesmo tempo narradores e protagonistas dos enfrentamentos nas ruas, com a proposta de narrativa independente, estavam amparados pelos dispositivos portáteis do momento, em especial, os celulares. Talvez sem ter isso em mente, a Mídia Ninja acabou sendo filtro do olhar do centro nervoso dos protestos à Grande Imprensa, muitas vezes proibida de ocupar o Mundo da Vida por sua atuação que passa não apenas pelo quesito econômico, mas também por sua linguagem mediadora do relato, além da condição sígnica do capital. Bucci considera que a Mídia Ninja nasceu para socorrer o mainstream, porém, discordamos disso e convidamos o leitor a fazer este raciocínio. Pensamos que ela surgiu como recado à atividade jornalística tradicional, mostrando que também pode ter credibilidade nascendo da mais acessada forma de comunicação atual: as redes sociais. Se por um lado, as redes sociais viabilizam gravar, recortar e editar imagens, por outro, elas também podem ser vistas pela noção do fato social, como defende Ferdinand di Saussure ao reconhecer na linguagem a formação de uma coletividade. As definições de linguagem por Saussure são trazidas na discursividade de Bucci.

Outro teórico com quem o autor dialoga, ou para bem se apropriar da época, tece uma rede, é Mikhail Bakhtin, para quem os signos estão sempre em disputa e jamais se paralisam no tempo. Por isso, as “Jornadas de Junho” podem ser tidas como um fato social que atraiu uma linguagem capaz de gerar vários signos. Ainda no plano teórico, mais para o fim do livro, o autor trata de outros postulados que passam pela noção de Gozo de Jacques Lacan. 
Em nível prático, Bucci registra a natureza linguística de fatos frescos ao imaginário coletivo brasileiro contemporâneo, como as Eleições Presidenciais de 2014, os Protestos de 2015/2016, o impeachment de Dilma Rousseff e a Operação Lava Jato. Em suas últimas linhas, deixa a impressão de que seu ponto de partida desemboca em um momento muito mais jornalístico do que acadêmico, pois o Brasil vive uma ebulição capaz de produzir fatos inovadores, haja vista seu quadro instável e de quebra da ordem, materializado, por exemplo, nos Poderes Constituintes que se colocaram em rivalidade. A imprevisibilidade sobre o dia seguinte é o farejar do Jornalismo que vive de notícias novas. Por isso, cabe-nos dizer que as análises feitas no livro permitem deixar sujeitos a postos para contar, relatar ou narrar histórias que demarquem um registro o qual, anos adiante, a academia venha analisar e dar sua contribuição na tentativa de desvendar uma série de perguntas dúbias que povoam a atual conjuntura brasileira. Provocação instigante que Eugênio Bucci nos deixa neste livro.

\section{Rodrigo Gabrioti}

Doutorando pelo Programa de Pós-Graduação em Comunicação Social pela Universidade Metodista de São Paulo (UMESP). Graduado em Comunicação e mestre em Comunicação e Cultura pela Universidade de Sorocaba. É professor do curso de Comunicação Social - Jornalismo na Faculdade ESAMC Sorocaba e integra o Grupo de Pesquisa América Latina, Mídia, Culturas e Tecnologias Digitais, da Intercom. E-mail: rgabrioti@hotmail.com.

Recebido em: 09.01.2017

Aceito em: 28.06.2017 